\title{
Hydrolytic method for processing bismuth to obtain compounds
}

\author{
Artem S. Daminov ${ }^{1}$, Ekaterina S. Koledova ${ }^{2}$, Kseniya V. Mishchenko ${ }^{2}$, Yuri M. Yukhin ${ }^{2}$ \\ ${ }^{1}$ Novosibirsk Rare Metal Plant, Novosibirsk Region, Russia \\ ${ }^{2}$ Institute of Solid State Chemistry and Mechanochemistry SB RAS
}

\begin{abstract}
The hydrolytic processing of metallic bismuth to obtain compounds was investigated by methods of chemical, X-ray diffraction analyses, thermogravimetric analyzes, as well as electron microscopy. The conditions for obtaining bismuth nitrate pentahydrate composition $\mathrm{Bi}\left(\mathrm{NO}_{3}\right)_{3} \cdot 5 \mathrm{H}_{2} \mathrm{O}$, oxide, citrate of bismuth of composition $\mathrm{BiC}_{6} \mathrm{H}_{5} \mathrm{O}_{7}$, bismuth-potassium-ammonium citrate and oxohydroxotribromophenolate of bismuth of the pharmacopoeial composition $\left[\mathrm{Bi}_{6} \mathrm{O}_{6}(\mathrm{OH})_{2}\right]\left(\mathrm{C}_{6} \mathrm{H}_{2} \mathrm{Br}_{3} \mathrm{O}\right)_{4}$ Xeroform are presented.
\end{abstract}

Bismuth is a rare metal. Various estimates show that its average content in the Earth's crust ranges from $9 \cdot 10^{-7}$ to $2 \cdot 10^{-5} \%$, while the annual global consumption of bismuth is 15 16 thousand tons per year. Meanwhile, the consumption rate of bismuth in the form of its compounds is estimated at $57.2 \%$ [1]. Production of bismuth compounds involves hydrolytic processing of nitric acid solutions, since nitric acid is one of the best solvents for bismuth metal. Nitric or hydrochloric acid solutions are usually used in hydrometallurgy for processing bismuth-containing materials. Bismuth metal is almost insoluble in hydrochloric acid solutions, while its dissolution in nitric acid is accompanied by the release of toxic nitrogen oxides into the gas phase.

The aim of this work is to develop environmentally friendly processes for the processing of metallic bismuth with the production of basic and secondary nitrates, oxide, oxohydroxotribromophenolate, bismuth citrate and bismuth-potassium-ammonium citrate of high purity.

To perform bismuth oxidation, the powders produced by adding ammonium nitrate or sodium chloride to the bismuth metal melt $\left(\mathrm{T}_{\text {melt }}=271^{\circ} \mathrm{C}\right)$ were analyzed [2]. Thus, after the powder obtained by adding sodium chloride $(20 \%)$ to the bismuth metal melt was heated to $350^{\circ} \mathrm{C}$, followed by stirring the mixture for $10 \mathrm{~min}$, cooling down, and washing with water, the X-ray diffraction patterns contain the characteristic peaks corresponding to bismuth metal and monoclinic bismuth $\alpha$-oxide. The product obtained by further calcination at $350^{\circ} \mathrm{C}$ for $4 \mathrm{~h}$ is a mixture of monoclinic bismuth $\alpha$-oxide and bismuth oxochloride $\mathrm{Bi}_{12} \mathrm{O}_{17} \mathrm{Cl}_{2}$, which can be used during production of hydrochloric acid solutions.

The XRD data showed that after adding $20 \%$ ammonium nitrate to the bismuth melt at $350^{\circ} \mathrm{C}$, cooling down the mixture and washing it with water at $60^{\circ} \mathrm{C}$, the XRD patterns contained the main reflections corresponding to bismuth metal and monoclinic bismuth 
oxide (Fig. 1, curves 1 and 2). The XRD pattern also contains some additional reflections corresponding to bismuth oxohydroxonitrate $\mathrm{Bi}_{5} \mathrm{O}_{6}\left(\mathrm{NO}_{3}\right)_{2}(\mathrm{OH})$ and reflections from bismuth oxonitrate $\mathrm{Bi}_{5} \mathrm{O}_{7} \mathrm{NO}_{3}$ correlating with the database. However, quantitative analysis of the phase composition shows that the content of bismuth metal in the mixture remains $52 \%$. Further calcination of the mixture at $350^{\circ} \mathrm{C}$ for $4 \mathrm{~h}$ makes it possible to convert bismuth metal almost completely to its oxide and facilitates the decomposition of bismuth nitrates (Fig. 1, curve 3). The content of bismuth nitrates in the product is $\leq 5 \%$, and the product can be used to produce bismuth-containing nitric acid solutions.

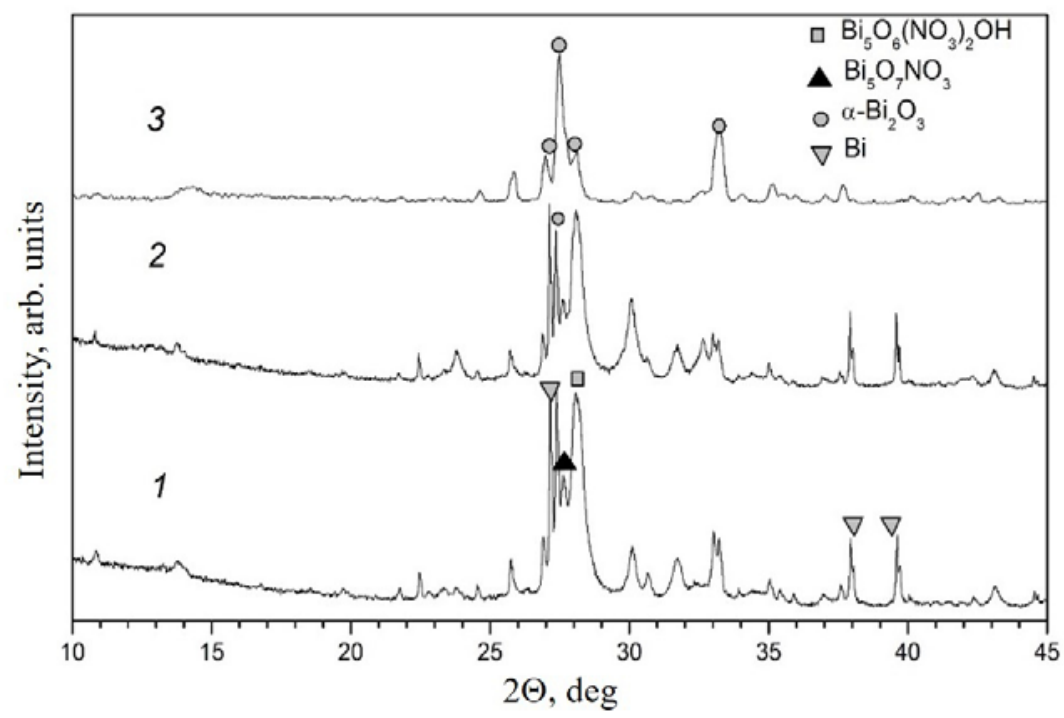

Fig. 1. The X-ray diffraction patterns of the products prepared by adding $20 \%$ ammonium nitrate to bismuth melt during stirring and cooling (1), followed by washing with water at $60^{\circ} \mathrm{C}(2)$ and calcination at $350^{\circ} \mathrm{C}$ for $4 \mathrm{~h} \mathrm{(3)}$.

Therefore, the conversion of bismuth metal to its oxide can be performed via preliminary dispersion of the metal by adding $20 \mathrm{wt} \%$ ammonium nitrate or sodium chloride at $(350 \pm 20){ }^{\circ} \mathrm{C}$ to the melt and stirring it. Bismuth nitrate and chloride solutions containing 500 and $400 \mathrm{~g} / \mathrm{L}$ of bismuth, respectively, were obtained by dissolving these products in $6 \mathrm{M}$ nitric or hydrochloric acids. The use of nitric acid allows one to reduce its consumption and prevent the release of toxic nitrogen oxides into the atmosphere, since the dissolution reactions of bismuth metal and bismuth oxide proceed via Eqs. (1) and (2), respectively:

$$
\begin{aligned}
& \mathrm{Bi}+6 \mathrm{HNO}_{3} \rightarrow \mathrm{Bi}\left(\mathrm{NO}_{3}\right)_{3}+3 \mathrm{NO}_{2} \uparrow+3 \mathrm{H}_{2} \mathrm{O} \\
& \mathrm{Bi}_{2} \mathrm{O}_{3}+6 \mathrm{HNO}_{3} \rightarrow 2 \mathrm{Bi}\left(\mathrm{NO}_{3}\right)_{3}+3 \mathrm{H}_{2} \mathrm{O}
\end{aligned}
$$

Bismuth nitrate composition $\mathrm{Bi}\left(\mathrm{NO}_{3}\right)_{3} \cdot 5 \mathrm{H}_{2} \mathrm{O}$ is usually produced from bismuth metal via its dissolution in concentrated $(\sim 14 \mathrm{M})$ nitric acid under gentle heating and subsequent cooling of the solution [3]. The bismuth dissolution reaction proceeds via Eq. (1), and acid vapor is released to the atmosphere along with water vapor during production of bismuth nitrate pentahydrate.

At ambient temperature, the solubility curve of the $\mathrm{Bi}_{2} \mathrm{O}_{3}-\mathrm{H}_{2} \mathrm{O}-\mathrm{HNO}_{3}$ system contains two crystallization regions. The degree of bismuth transition to the solution is limited by its hydrolysis yielding a precipitate of basic bismuth nitrate when there is lack of acid, while being limited by the formation of a precipitate of bismuth nitrate pentahydrate when there is 
an excessive amount of acid. Figure 2 shows that bismuth nitrate pentahydrate can be obtained at ambient temperature via the interaction between bismuth oxide and a concentrated nitric acid solution. It can also be obtained from concentrated solutions containing excessive amounts of bismuth $(\sim 620 \mathrm{~g} / \mathrm{L})$ produced by dissolution of bismuth oxide in concentrated $(12-15 \mathrm{M})$ solutions of nitric acid at $60-70^{\circ} \mathrm{C}$ followed by their cooling down.

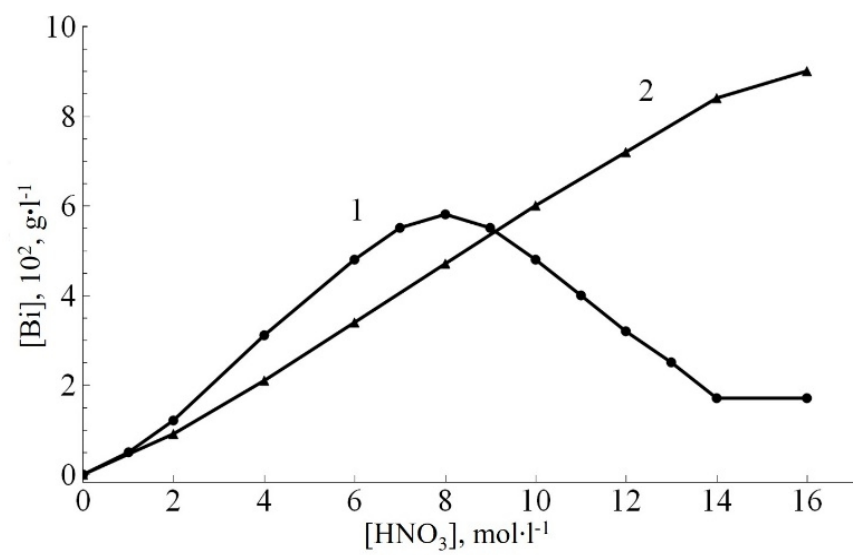

Fig. 2. Bismuth concentration in the solution as a function of the initial concentration of nitric acid during the dissolution of $\mathrm{Bi}_{2} \mathrm{O}_{3}$ : (1) $22^{\circ} \mathrm{C}$ and (2) $60^{\circ} \mathrm{C}$.

Impurity metals are removed from bismuth most efficiently during the hydrolysis of bismuth-containing solutions of nitric acid by adding water to them at temperatures $\geq 50^{\circ} \mathrm{C}$. However, even when the solutions are diluted with water 30 -fold, not more than $90 \%$ of bismuth is precipitated. Thus, when the initial bismuth-containing solution was added to distilled water pre-heated to $70^{\circ} \mathrm{C}$ at the $5: 1$ volume ratio between water and the bismuthcontaining solution, the degree of bismuth extraction as a precipitate $(\mathrm{R})$ was $68.2 \%$, while being as high as $82.8 \%$ and $84.3 \%$ when the volume ratio was $9: 1$ and $14: 1$, respectively. Therefore, the bismuth-containing nitric solution $\left(380 \mathrm{~g} / \mathrm{L} \mathrm{Bi}, 110 \mathrm{~g} / \mathrm{L} \mathrm{HNO}_{3}\right)$ was processed at $(60 \pm 3)^{\circ} \mathrm{C}$ using the following procedure: the bismuth-containing solution was diluted tenfold with distilled water, and $\mathrm{pH}$ of the mixture was adjusted to 1 using aqueous solution of ammonia. Bismuth concentration was $0.92 \mathrm{~g} / \mathrm{L}$ in the mother liquor, $1.2 \mathrm{~g} / \mathrm{L}$ in the first washing solution, and $0.23 \mathrm{~g} / \mathrm{L}$ in the second washing solution. The degree of bismuth conversion to basic bismuth nitrate was $94.6 \%$.

According to the XRD data, bismuth is precipitated from its nitric acid solutions at $(60 \pm 3){ }^{\circ} \mathrm{C}$ and $\mathrm{pH} 1$ as a well-crystallizable oxohydroxonitrate $\left[\mathrm{Bi}_{6} \mathrm{O}_{4}(\mathrm{OH})_{4}\right]\left(\mathrm{NO}_{3}\right)_{6} \cdot \mathrm{H}_{2} \mathrm{O}$ having pronounced diffraction peaks: $\mathrm{d} / \mathrm{n}=7.55 ; 3.78 ; 3.29 ; 2.63 ; 2.18$; and $1.73 \AA$. According to the electron microscopy data (Fig. 3a), it consisted of cluster crystals shaped as short prisms (greatest basal plane dimension, 1-5 $\mu \mathrm{m}$; thickness, 1-3 $\mu \mathrm{m}$ ). During the stage of first washing of the precipitate with water, it is partially recrystallized as indicated by the XRD and electron microscopy data (Fig. 3b). According to the XRD data, it is completely converted to oxohydroxonitrate $\left[\mathrm{Bi}_{6} \mathrm{O}_{5}(\mathrm{OH})_{3}\right]\left(\mathrm{NO}_{3}\right)_{5} \cdot 3 \mathrm{H}_{2} \mathrm{O}$ (PDF No. 70-1226) during the second washing with water due to hydrolysis via the reaction

$$
\left[\mathrm{Bi}_{6} \mathrm{O}_{4}(\mathrm{OH})_{4}\right]\left(\mathrm{NO}_{3}\right)_{6} \cdot \mathrm{H}_{2} \mathrm{O}+2 \mathrm{H}_{2} \mathrm{O} \rightarrow\left[\mathrm{Bi}_{6} \mathrm{O}_{5}(\mathrm{OH})_{3}\right]\left(\mathrm{NO}_{3}\right)_{5} \cdot 3 \mathrm{H}_{2} \mathrm{O}+\mathrm{H}^{+}+\mathrm{NO}_{3}{ }^{-}
$$

According to the electron microscopy data, the resulting bismuth oxohydroxonitrate consists of elongated crystals shaped as short prisms (greatest basal plane dimension, 10-50 $\mu \mathrm{m}$; thickness, $\sim 1-5 \mu \mathrm{m}$ ) (Fig. 3c). 
Basic bismuth nitrate was produced during the commercial tests; the product contained bismuth oxide $(79.89 \%)$, lead $(0.0006 \%)$, zinc $(0.0001 \%)$, iron $(0.0005 \%)$, antimony $(<$ $0.0001 \%)$, copper $(0.0003 \%)$, silver $(0.0003 \%)$, arsenic $(<0.0001 \%)$, cadmium $(<$ $0.00005 \%)$, tellurium $(<0.0001 \%)$, calcium $(0.0004 \%)$, magnesium $(0.0004 \%)$; sodium $(0.0003 \%)$, chlorides $(<0.001 \%)$, ammonium salts $(<0.002 \%)$, carbonates $(<0.003 \%)$, and sulfates $(<0.005 \%)$, which complies with the Manufacturer's Monograph 42-0587612404.
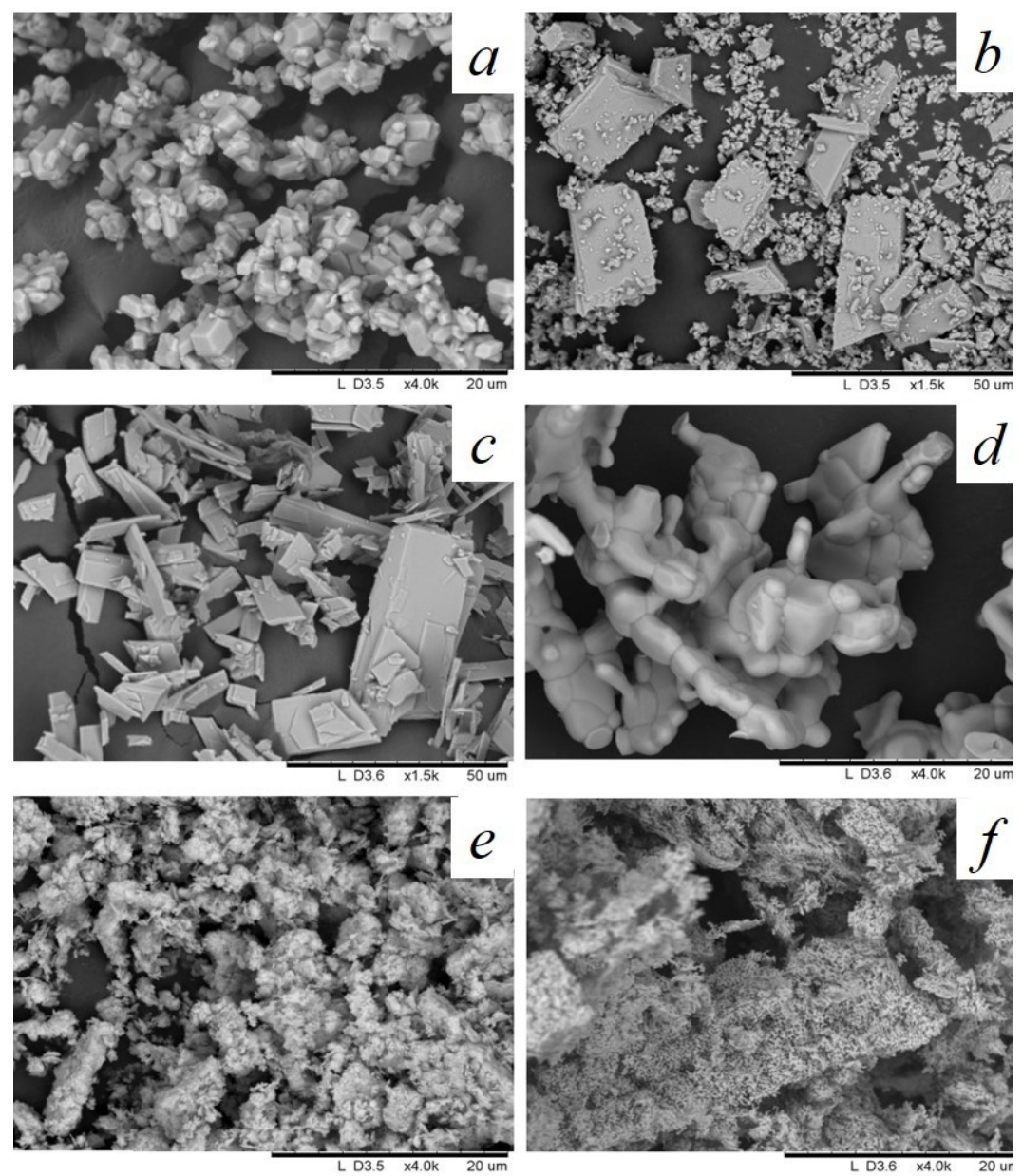

Fig. 3. Microimages of the samples of bismuth oxohydroxonitrate $\left[\mathrm{Bi}_{6} \mathrm{O}_{4}(\mathrm{OH})_{4}\right]\left(\mathrm{NO}_{3}\right)_{6} \cdot \mathrm{H}_{2} \mathrm{O}$ (a); a mixture of $\left[\mathrm{Bi}_{6} \mathrm{O}_{4}(\mathrm{OH})_{4}\right]\left(\mathrm{NO}_{3}\right)_{6} \cdot \mathrm{H}_{2} \mathrm{O}$ and $\left[\mathrm{Bi}_{6} \mathrm{O}_{5}(\mathrm{OH})_{3}\right]\left(\mathrm{NO}_{3}\right)_{5} \cdot 3 \mathrm{H}_{2} \mathrm{O}(\mathrm{b}) ;\left[\mathrm{Bi}_{6} \mathrm{O}_{5}(\mathrm{OH})_{3}\right]\left(\mathrm{NO}_{3}\right)_{5} \cdot 3 \mathrm{H}_{2} \mathrm{O}$ (c), oxide $\mathrm{Bi}_{2} \mathrm{O}_{3}$ (d) produced by thermal decomposition of (c); bismuth oxocarbonate $(\mathrm{BiO})_{2} \mathrm{CO}_{3}(\mathrm{e})$, and bismuth oxide (e) produced by thermal decomposition of (e).

The degree of direct conversion of bismuth metal to the product is $94.6 \%$ [4]; specific surface area of the resulting basic nitrate is $0.58 \mathrm{~m}^{2} / \mathrm{g}$; and bulk density is $1.55 \mathrm{~g} / \mathrm{cm}^{3}$.

According to the XRD data, calcination of bismuth oxohydroxonitrate at $(620 \pm 20){ }^{\circ} \mathrm{C}$ has yielded monoclinic bismuth oxide (PDF No. 14-699). Bismuth oxide particles are clusters of molten grains with the total size of 10-30 $\mu \mathrm{m}$ (Fig. 3d). The grains forming the cluster are sized 2-6 $\mu \mathrm{m}$. The weight fraction of the main compound in the oxide is $99.6 \%$, while the impurity content is as follows: nitrogen, $0.005 \%$; sulfates, $<0.005 \%$; chlorides, $<$ $0.001 \%$; iron, $0.0009 \%$; calcium, $0.0006 \%$; magnesium, $0.0006 \%$; sodium, $0.0005 \%$; copper, $0.0005 \%$; lead, $0.0008 \%$; and silver, $0.0006 \%$, which complies with State Standard 
GOST 10216-75 for the chemically pure grade. The specific surface area of the resulting oxide is $0.52 \mathrm{~m}^{2} / \mathrm{g}$; its bulk density is $1.90 \mathrm{~g} / \mathrm{cm}^{3}$.

In order to produce fine-grained bismuth oxide and prevent the release of nitrogen oxide into the gas phase during the stage involving calcination of basic bismuth nitrate, we have considered the option when the compound is preliminarily converted to basic bismuth carbonate by treating it with ammonium carbonate at a molar ratio between ammonium carbonate and basic bismuth nitrate of 0.55 .

Treating bismuth oxohydroxonitrate $\left[\mathrm{Bi}_{6} \mathrm{O}_{5}(\mathrm{OH})_{3}\right]\left(\mathrm{NO}_{3}\right)_{5} \cdot 3 \mathrm{H}_{2} \mathrm{O}$ with ammonium carbonate solution at $\mathrm{pH} \geq 8$ leads to replacement of nitrate ions with carbonate ions yielding bismuth oxocarbonate $(\mathrm{BiO})_{2} \mathrm{CO}_{3}$ (PDF No. 84-1752) via reaction:

$$
\begin{aligned}
{\left[\mathrm{Bi}_{6} \mathrm{O}_{5}(\mathrm{OH})_{3}\right] } & \left(\mathrm{NO}_{3}\right)_{5} \cdot 3 \mathrm{H}_{2} \mathrm{O}+3\left(\mathrm{NH}_{4}\right)_{2} \mathrm{CO}_{3} \rightarrow \\
& \rightarrow 3(\mathrm{BiO})_{2} \mathrm{CO}_{3}+5 \mathrm{NH}_{4} \mathrm{NO}_{3}+\mathrm{NH}_{4} \mathrm{OH}+4 \mathrm{H}_{2} \mathrm{O}
\end{aligned}
$$

Bismuth oxocarbonate is a bulk structure consisting of clusters of lamellar crystals, with aggregate size of 5-10 $\mu \mathrm{m}$ (Fig. 3e). The specific surface area of the product is $3.5 \mathrm{~m}^{2} / \mathrm{g}$; the bulk density is $1.36 \mathrm{~g} / \mathrm{cm}^{3}$. Calcining bismuth oxocarbonate at $(380 \pm 20){ }^{\circ} \mathrm{C}$ for $5 \mathrm{~h}$ yielded bismuth oxide of chemically pure grade, which consisted of molten lamellar crystals sized $\sim 0.5 \mu \mathrm{m}$ (Fig. $3 \mathrm{f}$ ). The specific surface area of the resulting bismuth oxide was $1.145 \mathrm{~m}^{2} / \mathrm{g}$; the bulk density was $1.81 \mathrm{~g} / \mathrm{cm}^{3}$.

When bismuth citrate is precipitated from nitric acid solutions, the degree of removing the main accompanying metals (lead and silver) from the product is insufficient. Therefore, we studied the process of synthesizing bismuth citrate via the exchange reaction between solid bismuth oxohydroxonitrate (BOHN) and citric acid solution. The experiments demonstrate that production of bismuth citrate by treating basic bismuth nitrate with an aqueous solution of citric acid at a 1.01-1.15 molar ratio between citrate ions and bismuth and at the weight ratio between the citric acid solution and basic bismuth nitrate of 2.06-6.0 allows one to completely convert basic bismuth nitrate to bismuth citrate within one hour.

The interaction between basic bismuth nitrate and citric acid proceeds via the equation

$$
\left[\mathrm{Bi}_{6} \mathrm{O}_{4}(\mathrm{OH})_{4}\right]\left(\mathrm{NO}_{3}\right)_{6} \cdot \mathrm{H}_{2} \mathrm{O}+6 \mathrm{H}_{3} \mathrm{C}_{6} \mathrm{H}_{5} \mathrm{O}_{7} \rightarrow 6 \mathrm{BiC}_{6} \mathrm{H}_{5} \mathrm{O}_{7}+6 \mathrm{HNO}_{3}+12 \mathrm{H}_{2} \mathrm{O} \text {. }
$$

In order to produce bismuth-potassium-ammonium citrate, the bismuth citrate precipitate was treated with a solution containing potassium hydroxide and citric acid. An aqueous solution of ammonia was added to the mixture until $\mathrm{pH} 8$, and the dissolution was performed at $70^{\circ} \mathrm{C}$ for $3 \mathrm{~h}$ [5]. Bismuth-potassium-ammonium citrate was obtained after vacuum drying of the solution; this compound is used by Velpharm OJSC (Kurgan, Russia) to manufacture Russian antiulcer medication Vitridinol ${ }^{\circledR}$, an analog of De-Nol ${ }^{\circledR}$ (the Netherlands).

Bismuth 2,4,6-tribromophenolate is widely used in medicine as the drug Xeroform. The studies focused on production of bismuth oxohydroxotribromophenolate by adding sodium acetate and bismuth nitrate solution to sodium tribromophenolate at $20-25^{\circ} \mathrm{C}$ indicate that $\mathrm{pH}$ of the reaction mixture at the initial stage is $1.8-2.0$. According to the $\mathrm{XRD}$ analysis (Fig. 4, curve 1), compound $\left[\mathrm{Bi}_{6} \mathrm{O}_{5}(\mathrm{OH})_{3}\right]\left(\mathrm{NO}_{3}\right)_{5} \cdot 3 \mathrm{H}_{2} \mathrm{O}$ is formed. As $\mathrm{pH}$ of the mixture is increased by adding an aqueous sodium hydroxide solution, the $\mathrm{X}$-ray amorphous oxohydroxonitrate $\left[\mathrm{Bi}_{6} \mathrm{O}_{6}(\mathrm{OH})_{2}\right]\left(\mathrm{NO}_{3}\right)_{4} \cdot 2 \mathrm{H}_{2} \mathrm{O}$ (Fig. 4, curve 2) is formed within pH 3-6 at $25-30^{\circ} \mathrm{C}$. Chemical analysis of the precipitate indicates that it contains $75.2 \%$ of bismuth and $14.9 \%$ of nitrate ions; the molar ratio between bismuth and nitrate ions is 1.5 .

When temperature is increased to $95^{\circ} \mathrm{C}, \mathrm{pH}$ of the reaction mixture is raised to $6.5-7.5$, and stirring time is increased to $8 \mathrm{~h}$, nitrate ions are replaced with tribromophenol ions yielding bismuth oxohydroxotribromophenolate via the reaction: 


$$
\begin{aligned}
{\left[\mathrm{Bi}_{6} \mathrm{O}_{6}(\mathrm{OH})_{2}\right] } & \left(\mathrm{NO}_{3}\right)_{4} \cdot 2 \mathrm{H}_{2} \mathrm{O}+4\left(\mathrm{C}_{6} \mathrm{H}_{2} \mathrm{Br}_{3} \mathrm{ONa}\right) \rightarrow \\
& \rightarrow\left[\mathrm{Bi}_{6} \mathrm{O}_{6}(\mathrm{OH})_{2}\right]\left(\mathrm{C}_{6} \mathrm{H}_{2} \mathrm{Br}_{3} \mathrm{O}\right)_{4}+4 \mathrm{NaNO}_{3}+2 \mathrm{H}_{2} \mathrm{O}
\end{aligned}
$$

Bismuth content in this compound is $46.3 \%$; carbon content, $10.4 \%$; nitrogen content, $0.23 \%$; and hydrogen content, $0.42 \%$. The XRD pattern of the product is shown in Fig. 4 (curve 3).

It should be mentioned that increasing $\mathrm{pH}$ of the reaction mixture above 7.5 leads to formation of compounds $\mathrm{Bi}_{6} \mathrm{O}_{6}(\mathrm{OH})_{2}\left(\mathrm{NO}_{3}\right)_{3}$ and $\mathrm{Bi}_{6} \mathrm{O}_{7}(\mathrm{OH})_{2}\left(\mathrm{NO}_{3}\right)_{2} \cdot 2 \mathrm{H}_{2} \mathrm{O}$, which prevents the formation of bismuth oxohydroxotribromophenolate.

Production of bismuth oxohydroxotribromophenolate when the reagents are added in the reverse order is also of practical interest. Thus, when sodium tribromophenolate solution is added to bismuth-containing solution of nitric acid containing sodium acetate under stirring at $(25 \pm 5){ }^{\circ} \mathrm{C}$, bismuth oxohydroxonitrate $\left[\mathrm{Bi}_{6} \mathrm{O}_{4}(\mathrm{OH})_{4}\right]\left(\mathrm{NO}_{3}\right)_{6} \cdot 4 \mathrm{H}_{2} \mathrm{O}$ is formed at the initial stage within the $\mathrm{pH}$ range of $0.2-0.8$. The $\mathrm{XRD}$ pattern of this compound is shown in Fig. 4 (curve 4). As $\mathrm{pH}$ is further increased by adding sodium hydroxide solution, compound

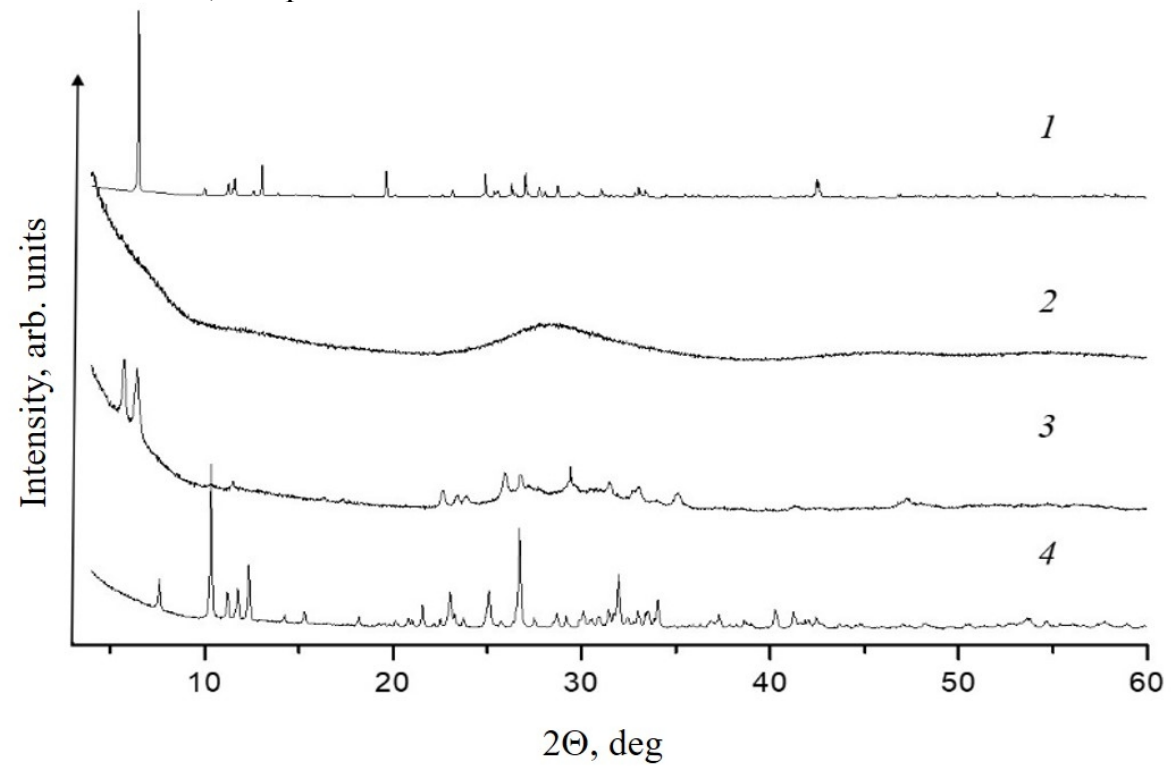

Fig. 4. The XRD patterns of compounds $\left[\mathrm{Bi}_{6} \mathrm{O}_{5}(\mathrm{OH})_{3}\right]\left(\mathrm{NO}_{3}\right)_{5} \cdot 3 \mathrm{H}_{2} \mathrm{O}(1),\left[\mathrm{Bi}_{6} \mathrm{O}_{6}(\mathrm{OH})_{2}\right]\left(\mathrm{NO}_{3}\right)_{4} \cdot 2 \mathrm{H}_{2} \mathrm{O}$ (2), $\left[\mathrm{Bi}_{6} \mathrm{O}_{6}(\mathrm{OH})_{2}\right]\left(\mathrm{C}_{6} \mathrm{H}_{2} \mathrm{Br}_{3} \mathrm{O}_{3}\right)_{4}(3)$, and $\left[\mathrm{Bi}_{6} \mathrm{O}_{4}(\mathrm{OH})_{4}\right]\left(\mathrm{NO}_{3}\right)_{6} \cdot 4 \mathrm{H}_{2} \mathrm{O}$ (4).

$\left[\mathrm{Bi}_{6} \mathrm{O}_{5}(\mathrm{OH})_{3}\right]\left(\mathrm{NO}_{3}\right)_{5} \cdot 3 \mathrm{H}_{2} \mathrm{O}$ is formed at $\mathrm{pH}$ 1.0-2.8 identically to the case described previously, while compound $\left[\mathrm{Bi}_{6} \mathrm{O}_{6}(\mathrm{OH})_{2}\right]\left(\mathrm{NO}_{3}\right)_{4} \cdot 2 \mathrm{H}_{2} \mathrm{O}$ is formed at $\mathrm{pH} 3.0-7.0$. Therefore, when producing bismuth oxohydroxotribromophenolate, the initial stage of synthesis is performed from acidic media ( $\mathrm{pH} 0.2-2.0$ ) in both cases, while the final $\mathrm{pH}$ value attained during the synthesis is $\leq 8.0$.

As a raw material for the production of bismuth compounds, a Bil grade metal is used, providing at least $98.0 \%$ of bismuth used with impurities in which lead and silver are used. Table summarizes the data on contents of impurity metals in bismuth metal of Bil grade, bismuth oxohydroxonitrate, and bismuth oxohydroxotribromophenolate. One can see that the preliminary hydrolytic purification of bismuth by precipitating it from nitric acid solutions in the form of oxohydroxonitrate makes it possible to produce high-purity bismuth oxohydroxotribromophenolate. 
Table 1. Production of bismuth oxohydroxotribromophenolate from nitric acid solution and via the reaction between solid bismuth oxohydroxonitrate and sodium tribromophenolate solution.

\begin{tabular}{|c|c|c|c|c|c|c|c|c|}
\hline \multirow{2}{*}{$\begin{array}{l}\text { Sample } \\
\text { composi- } \\
\text { tion }\end{array}$} & \multicolumn{8}{|c|}{ Contents of impurity metals, $\%$} \\
\hline & $\mathrm{Pb}$ & $\mathrm{Zn}$ & $\mathrm{Sb}$ & $\mathrm{Cu}$ & $\mathrm{Ag}$ & As & $\mathrm{Fe}$ & $\mathrm{Te}$ \\
\hline$(1)$ & 0.71 & $1 \cdot 10^{-3}$ & $1 \cdot 10^{-3}$ & $3,3 \cdot 10^{-3}$ & $1 \cdot 10^{-1}$ & $2 \cdot 10^{-4}$ & $1 \cdot 10^{-3}$ & $1 \cdot 10^{-4}$ \\
\hline (2) & $1 \cdot 10^{-3}$ & $1 \cdot 10^{-4}$ & $<1 \cdot 10^{-4}$ & $3 \cdot 10^{-4}$ & $3 \cdot 10^{-4}$ & $<5 \cdot 10^{-5}$ & $5 \cdot 10^{-4}$ & $<1 \cdot 10^{-4}$ \\
\hline (3) & 0.32 & $3 \cdot 10^{-4}$ & $2 \cdot 10^{-4}$ & $1.2 \cdot 10^{-3}$ & $1.8 \cdot 10^{-2}$ & $<5 \cdot 10^{-5}$ & $1.8 \cdot 10^{-4}$ & $<1 \cdot 10^{-4}$ \\
\hline (4) & $8 \cdot 10^{-4}$ & $<4 \cdot 10^{-5}$ & $<1 \cdot 10^{-4}$ & $<1 \cdot 10^{-5}$ & $3 \cdot 10^{-5}$ & $<5 \cdot 10^{-5}$ & $1 \cdot 10^{-4}$ & $<1 \cdot 10^{-4}$ \\
\hline
\end{tabular}

(1) bismuth metal of Bil grade; (2) bismuth oxohydroxonitrate $\left[\mathrm{Bi}_{6} \mathrm{O}_{4}(\mathrm{OH})_{4}\right]\left(\mathrm{NO}_{3}\right)_{6} \cdot \mathrm{H}_{2} \mathrm{O}$; (3) bismuth oxohydroxotribromophenolate produced by adding sodium tribromophenolate to the initial bismuthcontaining solution of nitric acid; (4) bismuth oxohydroxotribromophenolate produced from bismuth oxohydroxonitrate.

Bismuth oxohydroxotribromophenolate was produced during the commercial tests; the product contained bismuth oxide $(51.6 \%)$, lead $(0.0008 \%)$, zinc $(0.0001 \%)$, antimony $(<$ $0.0001 \%)$, copper $(0.0003 \%)$, silver $(0.0003 \%)$, arsenic $(<0.0001 \%)$, iron $(0.0005 \%)$, and tellurium $(<0.0001 \%)$, which complies with the Manufacturer's Monograph 42-2556-88. The degree of direct conversion of bismuth metal to the product was $94.2 \%$; specific surface area was $27.8 \mathrm{~m}^{2} / \mathrm{g}$. Thus, the expediency of converting metallic bismuth into oxide by preliminary dispersing the metal with a melt of ammonium nitrate or sodium chloride at $20 \%(350 \pm 20){ }^{\circ} \mathrm{C}$ and stirring has been established, as well as the conditions for obtaining a composition of bismuth nitrate pentahydrate. $\mathrm{Bi}\left(\mathrm{NO}_{3}\right)_{3} \cdot 5 \mathrm{H}_{2} \mathrm{O}$, oxide, bismuth citrate of the composition $\mathrm{BiC}_{6} \mathrm{H}_{5} \mathrm{O}_{7}$, bismuth-potassium-ammonium citrate and bismuth oxohydroxotribromophenolate of the pharmacopoeial composition $\left[\mathrm{Bi}_{6} \mathrm{O}_{6}(\mathrm{OH})_{2}\right]\left(\mathrm{C}_{6} \mathrm{H}_{2} \mathrm{Br}_{3} \mathrm{O}_{3}\right)_{4}$.

This work was conducted within the framework of the budget projects AAAA-A17-117030310277-6 for ISSCM SB RAS.

\section{References}

1. The Russian Market of Bismuth in 2015: An Analytical Review (2015)

2. Y.M. Yukhin, K.V. Mishchenko, A. S. Daminov, Theor. Found. Chem. Eng. 51, 4 (2017)

3. G. Braue,r Handbuch der Präparativen Anorganischen Chemie in drei Bänden Ferdinand Enke (Verlag Stuttgart, 1954)

4. RF Patent 2657673 (2018)

5. RF Patent 2530897 (2014) 